Check for updates

Cite this: Chem. Sci., 2018, 9, 4083

\title{
Energetic insights into two electron transfer pathways in light-driven energy-converting enzymes $\uparrow$
}

\begin{abstract}
Keisuke Kawashima ${ }^{a}$ and Hiroshi Ishikita (D) *ab
We report redox potentials $\left(E_{\mathrm{m}}\right)$ for one-electron reduction for all chlorophylls in the two electron-transfer branches of water-oxidizing enzyme photosystem II (PSII), photosystem I (PSI), and purple bacterial photosynthetic reaction centers (PbRC). In PSI, $E_{\mathrm{m}}$ values for the accessory chlorophylls were similar in both electron-transfer branches. In PbRC, the corresponding $E_{\mathrm{m}}$ value was $170 \mathrm{mV}$ less negative in the active $L$-branch $\left(B_{L}\right)$ than in the inactive $M$-branch $\left(B_{M}\right)$, favoring $B_{L}{ }^{\cdot-}$ formation. This contrasted with the corresponding chlorophylls, $\mathrm{Chl}_{\mathrm{D} 1}$ and $\mathrm{Chl}_{\mathrm{D} 2}$, in PSII, where $E_{\mathrm{m}}\left(\mathrm{Chl}_{\mathrm{D} 1}\right)$ was $120 \mathrm{mV}$ more negative than $E_{m}\left(C_{D_{2}}\right)$, implying that to rationalize electron transfer in the $\mathrm{D} 1$-branch, $\mathrm{Ch}_{\mathrm{D} 1}$ would need to serve as the primary electron donor. Residues that contributed to $E_{m}\left(C_{D_{1}}\right)<E_{m}\left(C_{D_{2}}\right)$ simultaneously played a key role in (i) releasing protons from the substrate water molecules and (ii) contributing to the larger cationic population on the chlorophyll closest to the $\mathrm{Mn}_{4} \mathrm{CaO}_{5}$ cluster $\left(\mathrm{P}_{\mathrm{D} 1}\right)$, favoring electron transfer from water molecules. These features seem to be the nature of PSII, which needs to possess the protonexit pathway to use a protonated electron source-water molecules.
\end{abstract}

Received 26th January 2018

Accepted 28th March 2018

DOI: $10.1039 / \mathrm{c} 8 \mathrm{sc} 00424 \mathrm{~b}$

rsc.li/chemical-science

The crystal structures of photosystem II (PSII), photosystem I (PSI) and purple bacterial photosynthetic reaction centers from Rhodobacter sphaeroides (PbRC) show a pseudo-twofold axis of symmetry, forming the following heterodimeric protein subunit pairs: D1/D2 in PSII, PsaA/PsaB in PSI, and L/M in PbRC..$^{1-6}$ In $\mathrm{PbRC}$, electron-transfer branches ( $\mathrm{L}$ - and $\mathrm{M}$-branches) proceed from a pair of bacteriochlorophyll $a(\mathrm{BChl} a)\left(\mathrm{P}_{\mathrm{L}}\right.$ and $\left.\mathrm{P}_{\mathrm{M}}\right)$ via accessory $\mathrm{BChl} a\left(\mathrm{~B}_{\mathrm{L}}\right.$ and $\left.\mathrm{B}_{\mathrm{M}}\right)$, bacteriopheophytin $a(\mathrm{BPheo} a)$ $\left(\mathrm{H}_{\mathrm{L}}\right.$ and $\left.\mathrm{H}_{\mathrm{M}}\right)$, and ubiquinone $\left(\mathrm{Q}_{\mathrm{A}}\right.$ and $\left.\mathrm{Q}_{\mathrm{B}}\right)$. In PSII, the corresponding cofactors are the pair of chlorophyll $a(\mathrm{Chl} a)\left(\mathrm{P}_{\mathrm{D} 1}\right.$ and $\left.\mathrm{P}_{\mathrm{D} 2}\right)$, accessory Chl $a\left(\mathrm{Chl}_{\mathrm{D} 1}\right.$ and $\left.\mathrm{Chl}_{\mathrm{D} 2}\right)$, pheophytin $a(\mathrm{Pheo} a)$ $\left(\mathrm{Pheo}_{\mathrm{D} 1}\right.$ and $\left.\mathrm{Pheo}_{\mathrm{D} 2}\right)$, and plastoquinone $\left(\mathrm{Q}_{\mathrm{A}}\right.$ and $\left.\mathrm{Q}_{\mathrm{B}}\right)$ of $\mathrm{D} 1$ - and D2-branches, and in PSI, the pair of Chla and the $13^{2}$ epimer $^{7}$ $\left(\mathrm{P}_{\mathrm{A}}\right.$ and $\left.\mathrm{P}_{\mathrm{B}}\right)$, accessory Chl $a\left(\mathrm{~A}_{1 \mathrm{~A}}\right.$ and $\left.\mathrm{A}_{1 \mathrm{~B}}\right)$, acceptor Chl $a\left(\mathrm{~A}_{0 \mathrm{~A}}\right.$ and $\left.\mathrm{A}_{\mathrm{OB}}\right)$, and phylloquinone $\left(\mathrm{A}_{1 \mathrm{~A}}\right.$ and $\left.\mathrm{A}_{1 \mathrm{~B}}\right)$ of $\mathrm{A}$ - and B-branches (Fig. 1). In PSI (i.e., a type-I reaction center), electron transfer occurs in both A- and B-branches, ${ }^{8}$ whereas in PbRC and PSII (i.e., type-II reaction centers) electron transfer predominantly occurs along $\mathrm{L}-$ and D1-branches, respectively. In PbRC and PSII, excitation of BChl $a$ and Chla leads to charge separation on the $\mathrm{L}-$ and D1-branches and formation of the cationic $\left[\mathrm{P}_{\mathrm{L}} / \mathrm{P}_{\mathrm{M}}\right]^{++}$

${ }^{a}$ Department of Applied Chemistry, The University of Tokyo, 7-3-1 Hongo, Bunkyo-ku, Tokyo 113-8654, Japan. E-mail: hiro@appchem.t.u-tokyo.ac.jp

${ }^{b}$ Research Center for Advanced Science and Technology, The University of Tokyo, 4-6-1 Komaba, Meguro-ku, Tokyo 153-8904, Japan. Fax: +81-3-5452-5083; Tel: +81-3-54525056

$\dagger$ Electronic supplementary information (ESI) available. See DOI: $10.1039 / \mathrm{c} 8 \mathrm{sc} 00424 \mathrm{~b}$ and $\left[\mathrm{P}_{\mathrm{D} 1} / \mathrm{P}_{\mathrm{D} 2}\right]^{\cdot+}$ states, respectively (e.g., $\left.{ }^{9}\right)$. Regardless of the structural similarities between the two reaction centers, ${ }^{1}$ many features are different. ${ }^{9}$ The $\left[\mathrm{P}_{\mathrm{L}} / \mathrm{P}_{\mathrm{M}}\right]^{++}$state has a redox potential $\left(E_{\mathrm{m}}\right)$ of $500 \mathrm{mV}$ for one-electron oxidation ${ }^{10}$ and accepts an electron from an outer protein subunit, cytochrome $c_{2}$ (or tetraheme cytochrome in PbRC from Blastochloris viridis). The $\left[\mathrm{P}_{\mathrm{D} 1} / \mathrm{P}_{\mathrm{D} 2}\right]^{++}$state has a high $E_{\mathrm{m}}(>1100 \mathrm{mV})^{11-13}$ and ultimately abstracts electrons from the substrate water molecules at the catalytic $\mathrm{Mn}_{4} \mathrm{CaO}_{5}$ moiety in D1 via redox-active D1-Tyr161 (TyrZ). Redox-active D2-Tyr160 (TyrD) exists at the symmetrical position in D2. Basic D2-Arg180 and D2-His61 near TyrD on the $\mathrm{D} 2$ side contribute to the larger $\mathrm{P}_{\mathrm{D} 1}{ }^{-+}$population than $\mathrm{P}_{\mathrm{D} 2}{ }^{\cdot+}$ in $\left[\mathrm{P}_{\mathrm{D} 1} / \mathrm{P}_{\mathrm{D} 2}\right]^{0^{+},{ }^{13}}$ i.e., electrostatically pushing the cation onto $\mathrm{P}_{\mathrm{D} 1}{ }^{14}$ thereby favoring electron transfer from the substrate water molecules in D1. ${ }^{15}$ Unlike PbRC, which only requires an electron transfer pathway, PSII also requires a proton transfer pathway from the substrate water molecules because the water molecules are protonated electron sources. In PSII, the release of protons $\left(\mathrm{H}^{+}\right)$has been observed in response to changes in the oxidation state $\left(S_{n}\right)$ of the oxygen-evolving complex, and it occurs with a typical stoichiometry of $1: 0: 1: 2$ for the $S_{0} \rightarrow S_{1}$ $\rightarrow \mathrm{S}_{2} \rightarrow \mathrm{S}_{3} \rightarrow \mathrm{S}_{0}$ transitions, respectively. ${ }^{16}$ Proton transfer may proceed via different pathways depending on the S-state transitions. ${ }^{17-19}$ The nature of the proton-conducting O4-water chain ${ }^{20}$ which is composed exclusively of water molecules, is consistent with and may explain the $\mathrm{pH}$-independence of proton transfer in the $\mathrm{S}_{0}$ to $\mathrm{S}_{1}$ transition. ${ }^{16}$ On the other hand, the pH-dependent rate constant for the $\mathrm{S}_{2}$-to- $\mathrm{S}_{3}$ transition ${ }^{16}$ 

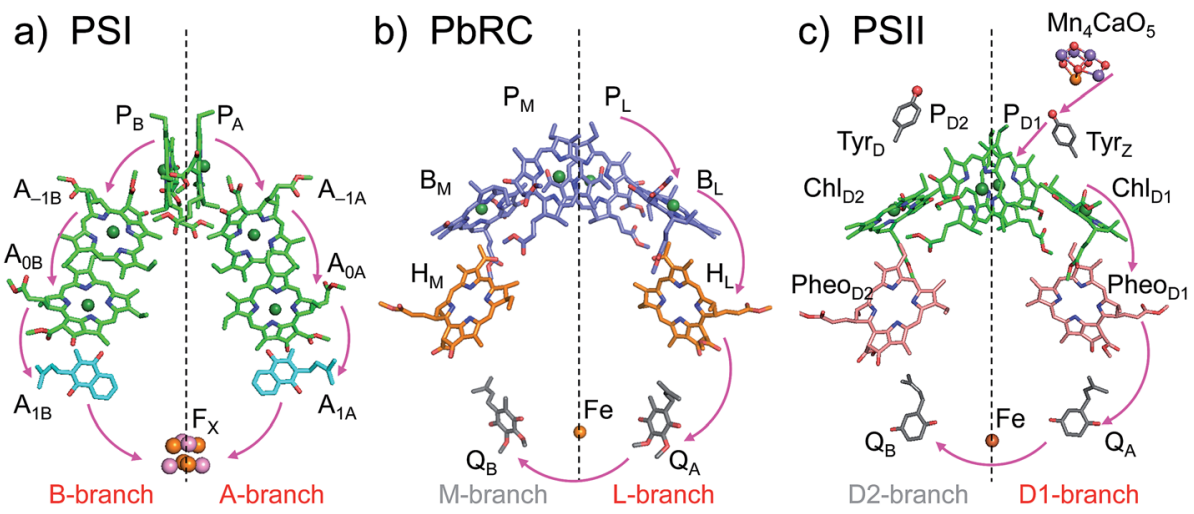

Fig. 1 Electron transfer chains in photosynthetic reaction centers of (a) PSI (PDB code 1JB0), (b) PbRC (PDB code 3I4D), and (c) PSII (PDB code $3 A R C$ ). Pink arrows indicate electron transfer. Dotted lines indicate pseudo- $C_{2}$ axes. Electron-transfer active branches are red labeled, whereas inactive branches are gray labeled.

indicates the involvement of ionizable groups in the proton transfer pathway (e.g., the pathway via D1-Asp61 21,22). Acquirement of the $\mathrm{Mn}_{4} \mathrm{CaO}_{5}$ cluster seems to induce a polar protein environment near the electron acceptor $\left[\mathrm{P}_{\mathrm{D} 1} / \mathrm{P}_{\mathrm{D} 2}\right]^{*+}$ and may alter the energetics of electron transfer along the D1-branch with respect to that along the L-branch in PbRC.

The free energy difference between cofactors (e.g., electron-

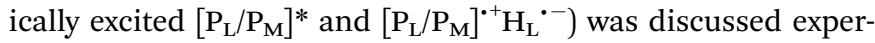
imentally $\left(\right.$ e.g..$\left.^{23}\right)$ and theoretically $\left(e . g .{ }^{24}\right)$. However, detailed $E_{\mathrm{m}}$ values of the cofactors for one-electron reduction in active Land D1-branches as well as inactive M- and D2-branches have not yet been experimentally determined and are a matter of debate $\left(e . g .{ }^{25}\right)$. Although we reported calculated $E_{\mathrm{m}}$ values for one-electron oxidation in PSI, PbRC, and PSII, ${ }^{13,26}$ these $E_{\mathrm{m}}$ values are more associated with distributions of the cationic states over the (B)Chla pairs (e.g., $\left[\mathrm{P}_{\mathrm{A}} / \mathrm{P}_{\mathrm{B}}\right]^{\cdot+}($ ref. 27$)$ and $\left[\mathrm{P}_{\mathrm{D} 1} / \mathrm{P}_{\mathrm{D} 2}\right]^{++}$ (ref. 13)). Due to a lack of $E_{\mathrm{m}}$ values of the cofactors for oneelectron reduction in PbRC, PSI, and PSII, it remains still unclear why electron transfer occurs in both A- and B-branches in PSI, whereas in PbRC and PSII electron transfer predominantly occurs along L- and D1-branches.

Here, we present $E_{\mathrm{m}}$ values of $\mathrm{Chl} a$, Pheo $a, \operatorname{BChl} a$, and BPheo $a$ for one-electron reduction in both electron-transfer branches of PbRC, PSI, and PSII; the $E_{\mathrm{m}}$ values were calculated using the crystal structures, solving the linear PoissonBoltzmann equation, and considering the protonation states of all titratable sites in the entire proteins.

\section{Results}

\section{$E_{\mathrm{m}}$ for accessory chlorophylls}

In PSI, $E_{\mathrm{m}}\left(\mathrm{A}_{1 \mathrm{~A}}\right)$ and $E_{\mathrm{m}}\left(\mathrm{A}_{1 \mathrm{~B}}\right)$ as well as $E_{\mathrm{m}}\left(\mathrm{A}_{0 \mathrm{~A}}\right)$ and $E_{\mathrm{m}}\left(\mathrm{A}_{0 \mathrm{~B}}\right)$ are at essentially the same level in the cyanobacterial ${ }^{2}$ (Fig. 2a) and plant ${ }^{6}$ (Fig. S1 $\dagger$ ) PSI crystal structures. $E_{\mathrm{m}}\left(\mathrm{A}_{0 \mathrm{~A}}\right)=-1042 \mathrm{mV}$ and $E_{\mathrm{m}}\left(\mathrm{A}_{0 \mathrm{~B}}\right)$ $=-1023 \mathrm{mV}$ (Fig. 2a), obtained using the cyanobacterial ${ }^{2}$ PSI crystal structure, are consistent with the experimentally estimated values, e.g., $E_{\mathrm{m}}\left(A_{0}\right)=-1050 \mathrm{mV}^{28}$ and $-1040 \mathrm{mV}^{.29}$

In PbRC, $E_{\mathrm{m}}\left(\mathrm{B}_{\mathrm{L}}\right)$ is $\sim 170 \mathrm{mV}$ less negative than $E_{\mathrm{m}}\left(\mathrm{B}_{\mathrm{M}}\right)$ based on the crystal structure analyzed at $2.01 \AA$ resolution (Protein
Data Bank (PDB) code 3I4D) (Fig. 2b). $E_{\mathrm{m}}\left(\mathrm{B}_{\mathrm{L}}\right)$ and $E_{\mathrm{m}}\left(\mathrm{B}_{\mathrm{M}}\right)$ were also calculated based on other PbRC crystal structures (e.g., PDB codes, $1 \mathrm{M} 3 \mathrm{X}^{3}$ and $1 \mathrm{EYS} ;{ }^{30} \mathrm{Fig}$. S2 $\dagger$ ) and show the same tendency.

In sharp contrast to $\mathrm{PbRC}, E_{\mathrm{m}}\left(\mathrm{Chl}_{\mathrm{D} 1}\right)$ is $120 \mathrm{mV}$ more negative than $E_{\mathrm{m}}\left(\mathrm{Chl}_{\mathrm{D} 2}\right)$ in the $1.9 \AA$ PSII crystal structure ${ }^{5}$ (Fig. 2c). At the $\mathrm{Chl}_{\mathrm{D} 1}$ and $\mathrm{Chl}_{\mathrm{D} 2}$ binding sites, "the PSII protein dielectric volume" (i.e., "uncharged protein volume", which is ultimately comprised of van der Waals radii of all protein atoms) decreases the solvation of the Chla cofactors, destabilizes Chl $a^{\cdot-}$, and thus lowers the $E_{\mathrm{m}}\left(\mathrm{Chl}_{\mathrm{D} 1}\right)$ and $E_{\mathrm{m}}\left(\mathrm{Chl}_{\mathrm{D} 2}\right)$ values. On the other hand, "the atomic charges of proteins" (i.e., "protein charges") also affect $E_{\mathrm{m}}(\mathrm{Chl} a)$; e.g., negatively charged groups destabilize $\mathrm{Chl} a^{\cdot-}$ and lower the $E_{\mathrm{m}}\left(\mathrm{Chl}_{\mathrm{D} 1}\right)$ and $E_{\mathrm{m}}\left(\mathrm{Chl}_{\mathrm{D} 2}\right)$ values. To identify the factors that differentiate between $E_{\mathrm{m}}\left(\mathrm{Chl}_{\mathrm{D} 1}\right)$ and $E_{\mathrm{m}}\left(\mathrm{Chl}_{\mathrm{D} 2}\right)$ in PSII, we analyzed contributions of "protein atomic charges" and "loss of solvation" to $E_{\mathrm{m}}\left(\mathrm{Chl}_{\mathrm{D} 1}\right)$ and $E_{\mathrm{m}}\left(\mathrm{Chl}_{\mathrm{D} 2}\right)$. Contributions of the protein atomic charges are predominantly responsible for the difference in the $E_{\mathrm{m}}$ values for accessory chlorophylls between PbRC and PSII, whereas contributions to $E_{\mathrm{m}}$ from the protein volume, which prevents the solvation of reduced accessory chlorophylls and thus lowers $E_{\mathrm{m}}$, are much smaller (Table 1).

$E_{\mathrm{m}}\left(\mathrm{PheO}_{\mathrm{D} 1}\right)$ is $-507 \mathrm{mV}$ (Fig. 2c), which is consistent with the value of $-499 \mathrm{mV}^{31}$ obtained using the $3.0 \AA$ PSII crystal structure (PDB code $2 \mathrm{AXT})^{32}$ and the spectroelectrochemically determined value of $-505 \mathrm{mV}^{33}$

\section{$\mathrm{B}_{\mathrm{L}}{ }^{\cdot-}$ stabilization in PbRC}

In PbRC, electronic excitation of BChla leads to the formation of the $\left(\mathrm{P}_{\mathrm{L}} / \mathrm{P}_{\mathrm{M}}\right)^{0+} \mathrm{B}_{\mathrm{L}}{ }^{\cdot-}$ state. ${ }^{34}$ Fig. 2 shows that $E_{\mathrm{m}}\left(\mathrm{B}_{\mathrm{L}}\right)$ is $170 \mathrm{mV}$ less negative than $E_{\mathrm{m}}\left(\mathrm{B}_{\mathrm{M}}\right)$, facilitating electron transfer along the L-branch. The asymmetry of the electron-transfer energetics is caused by the different contributions of charges on the residues and cofactors, not the different shapes of the proteins (e.g., solvent accessibility near each BChla) (Table 1). In particular, loop $a-b$ and helix $c d$ in the periplasm region and helix $d$ in the transmembrane region, which are structurally conserved in PSII (Fig. 3), helped to stabilize $\mathrm{B}_{\mathrm{L}}{ }^{\cdot{ }^{-}}$with respect to $\mathrm{B}_{\mathrm{M}}{ }^{\cdot-}$ (Table 2). Among the L/M-residue pairs, Phe-L181/Tyr-M210 in helix 
a) $\mathrm{PSI}$

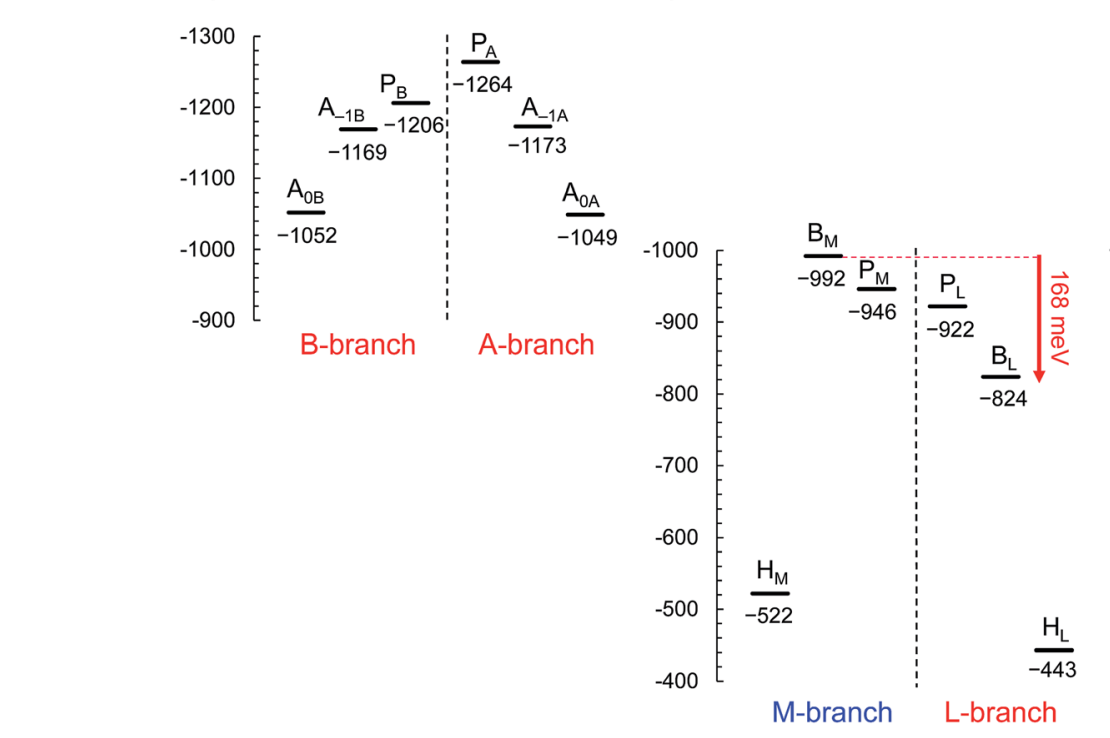

b) $\mathrm{PbRC}$ c) PSII

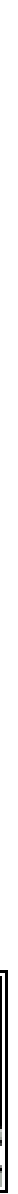

Fig. $2 E_{m}$ for one-electron reduction in the electron transfer chains in photosynthetic reaction centers of (a) PSI (PDB code 1JB0), (b) PbRC (PDB code 3I4D), and (c) PSII (PDB code $3 A R C$ ) in $\mathrm{mV}$. Red and blue arrows indicate the $E_{\mathrm{m}}$ difference between accessory (B)Chla cofactors in PbRC and PSII, respectively. The red wavy line indicates the weak electronic coupling (i.e., uncoupling) between $\mathrm{P}_{\mathrm{D} 1}$ and $\mathrm{P}_{\mathrm{D} 2}{ }^{49,50}$ Dotted lines indicate pseudo- $C_{2}$ axes. Electron-transfer active branches are red labeled, whereas inactive branches are blue labeled. See ref. 13 and 26 for calculated $E_{\mathrm{m}}$ values for one-electron oxidation in PSI, PbRC, and PSII.

Table 1 Contributions of the protein atomic charges and loss of solvation (i.e., due to protein volume, which prevents the solvation of reduced chlorophylls and thus lowers $E_{\mathrm{m}}$ ) to $E_{\mathrm{m}}$ for accessory chlorophylls in $\mathrm{mV}$. The $E_{\mathrm{m}}$ differences between the two electron-transfer branches are listed in the brackets

\begin{tabular}{|c|c|c|c|c|c|c|c|c|c|}
\hline \multirow{2}{*}{$\begin{array}{l}\text { Protein } \\
\text { Accessory chlorophyll }\end{array}$} & \multicolumn{3}{|l|}{ PSI } & \multicolumn{3}{|l|}{$\mathrm{PbRC}$} & \multicolumn{3}{|l|}{ PSII } \\
\hline & $\mathrm{A}_{-1 \mathrm{~B}}$ & $\mathrm{~A}_{-1 \mathrm{~A}}$ & & $\mathrm{P}_{\mathrm{M}}$ & $P_{L}$ & & $\mathrm{Chl}_{\mathrm{D} 2}$ & $\mathrm{Chl}_{\mathrm{D} 1}$ & \\
\hline$E_{\mathrm{m}}$ & -1169 & -1173 & $(-4)$ & -992 & -824 & $(168)$ & -825 & -942 & $(-117)$ \\
\hline In uncharged protein ${ }^{a}$ & -1085 & -1071 & (14) & -851 & -813 & $(38)$ & -1047 & -1058 & $(-11)$ \\
\hline In water & -798 & -798 & $(0)$ & -641 & -641 & $(0)$ & -798 & -798 & $(0)$ \\
\hline$E_{\mathrm{m}}$ shift (water to protein) & -371 & -375 & $(-4)$ & -351 & -183 & $(168)$ & -27 & -144 & $(-117)$ \\
\hline Due to protein charge & -84 & -102 & $(-18)$ & -141 & -11 & $(130)$ & 222 & 116 & $(-106)$ \\
\hline Due to loss of solvation & -287 & -273 & (14) & -210 & -172 & $(38)$ & -249 & -260 & $(-11)$ \\
\hline
\end{tabular}

$d\left(E_{\mathrm{m}}\left(\mathrm{B}_{\mathrm{L}}\right)-E_{\mathrm{m}}\left(\mathrm{B}_{\mathrm{M}}\right)=26 \mathrm{mV}\right)$, Tyr-L67/Glu-M95 in loop $a-$ $b(20 \mathrm{mV})$, and Asp-L155/Asp-M184 in helix $c d(22 \mathrm{mV})$ provide the greatest contribution to $E_{\mathrm{m}}\left(\mathrm{B}_{\mathrm{L}}\right)>E_{\mathrm{m}}\left(\mathrm{B}_{\mathrm{M}}\right)$ (Table 3).

(i) Asp-M184 and Glu-M95 at the binding interface of cytochrome $c_{2}$, decreasing $E_{m}\left(B_{M}\right)$. Table 3 shows that Glu-M95 and Asp-M184 contribute to decreasing $E_{\mathrm{m}}\left(\mathrm{B}_{\mathrm{M}}\right)(22 \mathrm{mV}$ and $37 \mathrm{mV}$, respectively) and thus stabilizing $\mathrm{B}_{\mathrm{L}}{ }^{--}$with respect to $\mathrm{B}_{\mathrm{M}}{ }^{\cdot-}$. From the observation of the PbRC-cytochrome $c_{2}$ co-crystal structure, Axelrod et al. concluded that Glu-M95 and AspM184 provide the largest electrostatic interaction with cytochrome $c_{2}$ (Fig. S3†). ${ }^{35}$ Notably, among the 17 PbRC mutants, mutation of Asp-M184 to Lys exhibits the largest change, with a decrease in the binding constant with cytochrome $c_{2}$ by a factor of $800 .^{36}$ Thus, negatively charged Asp-M184 likely contributes not only to binding of the one-electron donor of
PbRC (i.e., cytochrome $c_{2}$ ) but also to electron transfer along the L-branch.

(ii) How Tyr-M210 facilitates L-branch electron transfer. Among all L/M-residue pairs in PbRC, the difference in the Phe-L181/ Tyr-M210 pair in helix $d$ contributes to the $E_{\mathrm{m}}$ difference the most, i.e., increasing $E_{\mathrm{m}}\left(\mathrm{B}_{\mathrm{L}}\right)$ with respect to $E_{\mathrm{m}}\left(\mathrm{B}_{\mathrm{M}}\right)$, as suggested in theoretical analysis by Parson et al. ${ }^{37}$ (Table 3 ). Indeed, mutations of Tyr-M210 to phenylalanine decreased the initial electron transfer with a time constant from 3.5 ps to 16 ps. ${ }^{38}$ The PbRC crystal structure analyzed at $2.01 \AA$ (PDB code 3I4D) shows that the polar $-\mathrm{OH}$ group of Tyr-M210 is oriented toward $\mathrm{B}_{\mathrm{L}}$, thus stabilizing $\mathrm{B}_{\mathrm{L}}{ }^{--}$and increasing $E_{\mathrm{m}}\left(\mathrm{B}_{\mathrm{L}}\right)$. The $-\mathrm{OH}$ group cannot be oriented toward the methyl-keto (acetyl) group of $\mathrm{P}_{\mathrm{M}}$ because the methyl site, rather than the keto site, is near the -OH group of Tyr-M210 (Fig. 4a). 

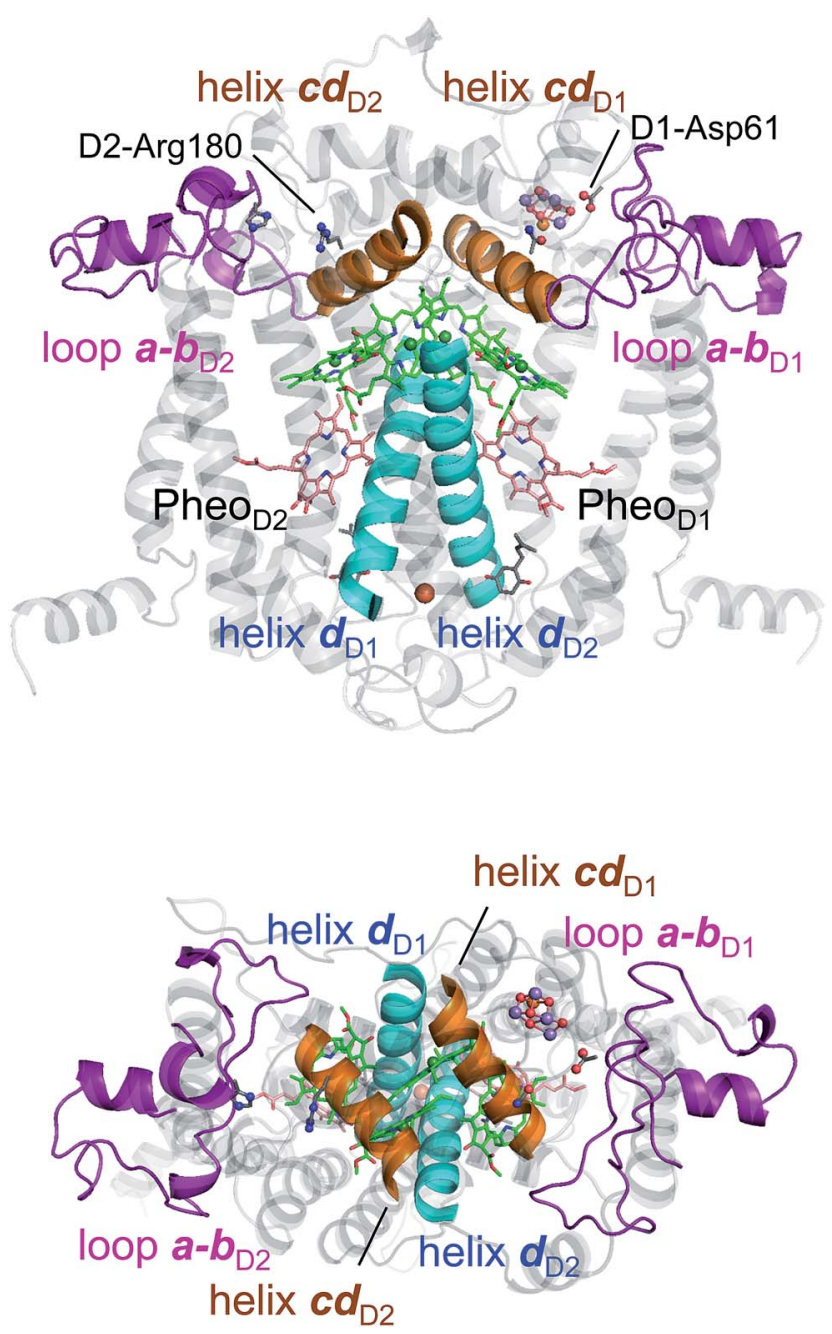

Fig. 3 Structural components of type-II reaction centers (e.g., PSII).

In contrast to the $2.01 \AA$ structure, the assignment of the methyl $\mathrm{C}$ and keto $\mathrm{O}$ atoms of $\mathrm{P}_{\mathrm{M}}$ is opposite in the PbRC crystal structure analyzed at $1.87 \AA$ (PDB code $2 \mathrm{~J} 8 \mathrm{C}$ ); ${ }^{4}$ the methyl-keto orientation allows the -OH group of Tyr-M210 to form an $\mathrm{H}$-bond with the keto $\mathrm{O}$ atom of $\mathrm{P}_{\mathrm{M}}\left(\mathrm{O}_{\mathrm{PM}}-\mathrm{O}_{\mathrm{Ty} \mathrm{rM} 210}=3.4 \AA\right.$; Fig. 4b). Thus, the methylketo orientation of $\mathrm{P}_{\mathrm{M}}$ in the $1.87 \AA$ structure cannot stabilize $\mathrm{B}_{\mathrm{L}}{ }^{--}$(Fig. S4 $\dagger$ ). However, the electron density map of all BChl $a$ and Pheo $a$ in the $1.87 \AA$ structure, ${ }^{4}$ except for $\mathrm{P}_{\mathrm{L}}$, indicates that the density is too low for the keto $\mathrm{O}$ atoms (red mesh in Fig. 4c), but too high for the methyl $\mathrm{C}$ atoms (green mesh in Fig. 4c) in the original assignment. Remarkably, the swapped assignment of the methyl-keto $\mathrm{O}$ and $\mathrm{C}$ atoms in $\mathrm{P}_{\mathrm{M}}, \mathrm{B}_{\mathrm{L}}, \mathrm{B}_{\mathrm{M}}, \mathrm{H}_{\mathrm{L}}$, and $\mathrm{H}_{\mathrm{M}}$ in the $1.87 \AA$ structure (refined $1.87 \AA$ structure), which is consistent with the original assignment in the $2.01 \AA$ structure, is in better agreement with the density with a decrease in an $R$-factor by $0.01 \%$ (Fig. $4 \mathrm{~d}$ ). Just by rotating the methyl-keto groups (forming the refined $1.87 \AA$ structure), the $E_{\mathrm{m}}$ difference, i.e., $E_{\mathrm{m}}\left(\mathrm{P}_{\mathrm{L}}\right)-E_{\mathrm{m}}\left(\mathrm{B}_{\mathrm{L}}\right)$, can be altered from $-8 \mathrm{mV}$ to $-72 \mathrm{mV}$ (Fig. S4†).

Hence, the methyl-keto orientations assigned in the $2.01 \AA$ structure (PDB code 3I4D) appear to be relevant to the PbRC conformation; the $-\mathrm{OH}$ group of Tyr-M210 is predominantly oriented toward $\mathrm{B}_{\mathrm{L}}$, stabilizing $\mathrm{B}_{\mathrm{L}}{ }^{\cdot-}$ and increasing $E_{\mathrm{m}}\left(\mathrm{B}_{\mathrm{L}}\right)$.
Table 2 Contributions of the protein components to $E_{\mathrm{m}}$ for accessory chlorophylls in PbRC and PSII in $\mathrm{mV}$. -, not applicable

\begin{tabular}{|c|c|c|c|c|}
\hline Region & Component & $\begin{array}{l}E_{\mathrm{m}}\left(\mathrm{B}_{\mathrm{L}}\right)- \\
E_{\mathrm{m}}\left(\mathrm{B}_{\mathrm{M}}\right) \\
\text { in PbRC }\end{array}$ & $\begin{array}{l}E_{\mathrm{m}}\left(\mathrm{Chl}_{\mathrm{D} 1}\right)- \\
E_{\mathrm{m}}\left(\mathrm{Chl}_{\mathrm{D} 2}\right) \\
\text { in PSII }\end{array}$ & Difference \\
\hline \multirow[t]{5}{*}{ Periplasm/lumen } & $\mathrm{Mn}_{4} \mathrm{CaO}_{5}{ }^{a}$ & - & 56 & - \\
\hline & $2 \mathrm{Cl}^{-}$ & - & -66 & - \\
\hline & Loop $a-b$ & 47 & -86 & -133 \\
\hline & Helix $c d$ & 40 & -91 & -131 \\
\hline & Others & -7 & 55 & 48 \\
\hline \multirow[t]{6}{*}{ Transmembrane } & Helix $a$ & -7 & 7 & 14 \\
\hline & Helix $b$ & -3 & 15 & 18 \\
\hline & Helix $c$ & 15 & -50 & -65 \\
\hline & Helix $d$ & 50 & 17 & -33 \\
\hline & Helix $e$ & -5 & 26 & 31 \\
\hline & Cofactors & 17 & -6 & -23 \\
\hline \multirow[t]{2}{*}{ Cytoplasm/stroma } & Subunit $\mathrm{H}$ & -2 & - & - \\
\hline & Others & 9 & 9 & 0 \\
\hline
\end{tabular}

Table 3 Contributions of residues in subunits $L$ and $M$ to $E_{m}\left(B_{L}\right)$ and $E_{m}\left(B_{M}\right)$ in $\mathrm{mV}$

\begin{tabular}{lrrllll}
\hline & & & & & & \\
& $E_{\mathrm{m}}\left(\mathrm{B}_{\mathrm{L}}\right)$ & $E_{\mathrm{m}}\left(\mathrm{B}_{\mathrm{M}}\right)$ & & $E_{\mathrm{m}}\left(\mathrm{B}_{\mathrm{L}}\right)$ & $E_{\mathrm{m}}\left(\mathrm{B}_{\mathrm{M}}\right)$ & $-E_{\mathrm{m}}\left(\mathrm{B}_{\mathrm{M}}\right)$ \\
\hline Phe-L181 & 0 & 22 & Tyr-M210 & 44 & -4 & 26 \\
Val-L157 & 19 & 0 & Thr-M186 & -1 & -4 & 22 \\
Tyr-L67 & 0 & 0 & Glu-M95 & -2 & -22 & 20 \\
Ser-L178 & -1 & -21 & Ala-M207 & -7 & -2 & 16 \\
Asp-L155 & -21 & -5 & Asp-M184 & -6 & -37 & 15
\end{tabular}

(iii) Low dielectric volume near $B_{M}$ provided by spheroidene and the $Q_{B}$ side chain. Around the Glu-M95/Asp-M184 moiety, approximately 30 hydrophobic residues from subunit $\mathrm{M}$ are in van der Waals contact with the carotenoid spheroidene (Fig. $\mathrm{S} 5 \dagger$ ). ${ }^{39}$ The electrostatic influence of the negative charges at the Glu-M95/Asp-M184 moiety is likely to be less screened at $B_{M}$ with respect to $B_{L}$, thus destabilizing $B_{M}{ }^{\cdot-}$. For the same reason, the cluster of hydrophobic residues seems also to enhance the polar -OH group of Tyr-M210 to stabilize $\mathrm{B}_{\mathrm{L}}{ }^{--}$. Hence, spheroidene, the cluster of hydrophobic residues, and the $\mathrm{Q}_{\mathrm{B}}$ isoprene side chain (see below) may be the origin of the low effective dielectric constant reported near $B_{M}$ with respect to $B_{L}$ in the Stark effect spectrum ${ }^{40}$ or the significantly small electric field along the M-branch suggested in electrostatic calculations. ${ }^{24}$ It should be noted that there are no water channels identified near $\mathrm{Chl}_{\mathrm{D} 1}$ and $\mathrm{Chl}_{\mathrm{D} 2}$ in the PSII crystal structures. ${ }^{41,42}$

(iv) The $Q_{B}$ isoprene side chain, decreasing specifically $E_{m}\left(B_{M}\right)$. The isoprene side chain of $Q_{B}$ is oriented toward $B_{M}$ and is partly in van der Waals contact with spheroidene, whereas that of $Q_{A}$ is oriented away from $B_{L}$ (Fig. $S 5 \dagger$ ).

The isoprene side chain of $\mathrm{Q}_{B}$ in the PbRC crystal structure analyzed at $2.01 \AA$ (PDB code $3 \mathrm{I} 4 \mathrm{D}$ ) is comprised of $56 \mathrm{C}$ atoms. When the side chain of $\mathrm{Q}_{\mathrm{B}}$ is shortened to $16 \mathrm{C}$ atoms, as identified in the $1.87 \AA$ PbRC crystal structure (PDB code $2 \mathrm{~J} 8 \mathrm{C}$ ), ${ }^{4}$ and the corresponding inner space is filled by water 
a)

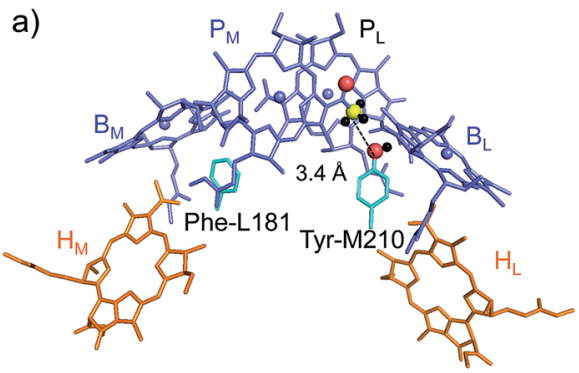

c)

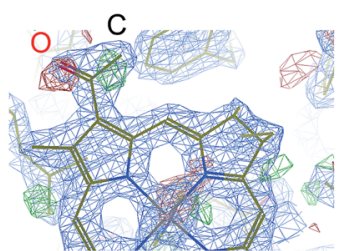

b)

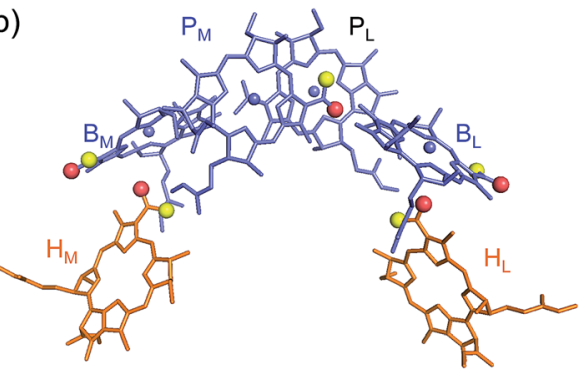

d)

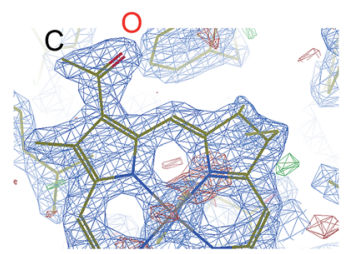

Fig. 4 (a) Orientations of the methyl-keto group in $\mathrm{P}_{\mathrm{M}}$ (yellow ball for methyl $\mathrm{C}$ and red ball for keto $\mathrm{O}$ ) and the hydroxyl group in Tyr-M210 (red ball for hydroxyl O) in the $2.01 \AA$-PbRC structure (PDB code 314D). (b) The methyl-keto groups in BChla and BPheoa (yellow balls for methyl C and red balls for keto $O$ ) in the $1.87 \AA$-PbRC structure (PDB code $2 \mathrm{~J} 8 \mathrm{C}),{ }^{4}$ whose assignments of the keto $\mathrm{O}$ atom and the methyl $\mathrm{C}$ atom are opposite to those in the $2.01 \AA$-PbRC structure (PDB code 314D). (c) The original assignment of the methyl-keto group of $B_{L}$ in the $1.87 \AA$-PbRC structure. The density is too low when the keto $O$ atom is assumed (red mesh), whereas too much when the methyl $C$ atom is assumed (green mesh). (d) The swapped assignment of the methyl-keto group of $B_{L}$ in the $1.87 \AA$-PbRC structure.

(represented implicitly with the dielectric constant $\varepsilon_{\mathrm{w}}=80$ ), changes in $E_{\mathrm{m}}$ are predominantly observed at $E_{\mathrm{m}}\left(\mathrm{B}_{\mathrm{M}}\right)$ with an increase of $57 \mathrm{mV}$ (Fig. S6b $\dagger$ ); this suggests that the isoprene chain of $\mathrm{Q}_{\mathrm{B}}$ also contributes to the hydrophobic protein environment specifically for $\mathrm{B}_{\mathrm{M}}$, enhancing electrostatic interactions and destabilizing $\mathrm{B}_{\mathrm{M}}{ }^{--}$.

\section{Factors that are responsible for $E_{\mathrm{m}}\left(\mathrm{Chl}_{\mathrm{D} 1}\right)<E_{\mathrm{m}}\left(\mathrm{Chl}_{\mathrm{D} 2}\right)$ in PSII}

Table 2 shows that loop $a-b(86 \mathrm{mV})$ and helix $c d(91 \mathrm{mV})$ in the lumen region (Fig. 3) are responsible for $E_{\mathrm{m}}\left(\mathrm{Chl}_{\mathrm{D} 1}\right)<E_{\mathrm{m}}\left(\mathrm{Chl}_{\mathrm{D} 2}\right)$ in PSII. Below we describe the key components that contribute to $E_{\mathrm{m}}\left(\mathrm{Chl}_{\mathrm{D} 1}\right)<E_{\mathrm{m}}\left(\mathrm{Chl}_{\mathrm{D} 2}\right)$.

(i) D1-Asp61/D2-His61 pair in loop $a-b$. In the stromal/lumen region, loop $a-b$ (that connects helices $a$ and $b$ ) and helix $c d$ (Fig. 3) seem most likely to characterize PSII with respect to PbRC (Table 2). Loop $a-b$ is comprised of 55 residues in D1 (D1: 55-109) and 54 residues in D2 (D2: 55-108), which are almost twice as long as that in PbRC (26 residues in subunit L (L: 57-82) and 34 residues in subunit $\mathrm{M}$ (M: 79-112)). The region D2Val55-Ser66 in PSII is structurally absent in PbRC (Fig. S7†). The insertion in PSII involves key residues for water oxidation, e.g., D1-Ile60 $\left(\mathrm{O}_{2}\right.$-exiting pathway $\left.{ }^{43}\right)$, D1-Asp61 (proton transfer pathway $^{22,44}$ ), D1-Glu65 (proton transfer pathway ${ }^{22,45}$ and water channel $^{42}$ ), and D2-His61 (proton transfer pathway for $\mathrm{TyrD}^{\mathbf{4 4 , 4 6 , 4 7}}$ ). In particular, the D1-Asp61/D2-His61 pair decreases $E_{\mathrm{m}}\left(\mathrm{Chl}_{\mathrm{D} 1}\right)$ by $98 \mathrm{mV}$ (Table 4$)$. The corresponding residues and proton transfer pathways are absent in PbRC.

(ii) D2-Arg180 in helix cd, specifically increasing $E_{m}\left(C h l_{D 2}\right)$. In PSII, lumenal helix $c d$ (D1: 176-190/D2: 176-188 for PSII, Fig. 3) decreases $E_{\mathrm{m}}\left(\mathrm{Chl}_{\mathrm{D} 1}\right)$ with respect to $E_{\mathrm{m}}\left(\mathrm{Chl}_{\mathrm{D} 2}\right)$ by $131 \mathrm{mV}$, whereas in PbRC, lumenal helix $c d$ (and L: 152-162/M: 179-192 for $\mathrm{PbRC}$ ) increases $E_{\mathrm{m}}\left(\mathrm{B}_{\mathrm{L}}\right)$ with respect to $E_{\mathrm{m}}\left(\mathrm{B}_{\mathrm{M}}\right)$ by $40 \mathrm{mV}$ (Table 2).
In particular, the D1-Asn181/D2-Arg180 pair in helix $c d$ decreases $E_{\mathrm{m}}\left(\mathrm{Chl}_{\mathrm{D} 1}\right)$ by $73 \mathrm{mV}$ with respect to $E_{\mathrm{m}}\left(\mathrm{Chl}_{\mathrm{D} 2}\right)$ (Table 4). D1-Asn181 also serves as the Cl-1 binding site ${ }^{5}$ in the proton-conducting E65/E312 water channel. ${ }^{42}$ D2-Arg180 is located at the entrance of the proton transfer pathway for TyrD ${ }^{\mathbf{4 4 , 4 6}}$ and provides the driving force. ${ }^{\mathbf{4 7}}$ Furthermore, the D1Asn181/A2-Arg180 pair is responsible for a larger $\mathrm{P}_{\mathrm{D} 1}{ }^{\cdot+}$ population than $\mathrm{P}_{\mathrm{D} 2}{ }^{\cdot+}$ (ref. 13), which facilitates electron transfer from substrate water molecules at the $\mathrm{Mn}_{4} \mathrm{CaO}_{5}$ moiety in D1.

(iii) Influence of $\mathrm{Mn}_{4} \mathrm{CaO}_{5} . \mathrm{E}_{\mathrm{m}}$ values calculated using the Mndepleted PSII crystal structure ${ }^{48}$ are similar to those obtained using the 1.9 A PSII crystal structure (Fig. S8 †). Calculated protonation states in the Mn-depleted PSII crystal structure show that the ligand residues (D1-Asp170, D1-Glu189, D1-His332, D1-Glu333, the carboxy-terminal D1-Ala344, and CP43-Glu354) and the H-bond partner (D1-His337) are fully protonated, which could compensate for loss of the cationic $\mathrm{Mn}_{4} \mathrm{CaO}_{5}$ cluster (Table S1 $\dagger$ ). Hence, the inorganic $\mathrm{Mn}_{4} \mathrm{CaO}_{5}$ component itself is not a main factor that determines $E_{\mathrm{m}}$ and the energetics of electron transfer. ${ }^{\mathbf{1 3 , 2 6}}$

\section{Discussion}

Different mechanism of single-branch electron transfer between PbRC and PSII

$E_{\mathrm{m}}\left(\mathrm{B}_{\mathrm{L}}\right)$ is $170 \mathrm{mV}$ less negative than $E_{\mathrm{m}}\left(\mathrm{B}_{\mathrm{M}}\right)$ in PbRC. In contrast, the corresponding $E_{\mathrm{m}}\left(\mathrm{Chl}_{\mathrm{D} 1}\right)$ value is $120 \mathrm{mV}$ more negative than $E_{\mathrm{m}}\left(\mathrm{Chl}_{\mathrm{D} 2}\right)$ in PSII. These controversial $E_{\mathrm{m}}$ profiles imply that the mechanisms of single-branch electron transfer are different between PbRC and PSII even though both are typeII reaction centers. The initial electron transfer from the $\mathrm{P}_{\mathrm{L}} / \mathrm{P}_{\mathrm{M}}$ pair to $\mathrm{B}_{\mathrm{L}}$ is $100 \mathrm{meV}$ downhill in the L-branch and $50 \mathrm{meV}$ uphill in the M-branch (Fig. 2). This energy difference should 
Table 4 Contributions of residues in $\mathrm{D} 1$ and $\mathrm{D} 2$ to $E_{\mathrm{m}}\left(\mathrm{Chl}_{\mathrm{D} 1}\right)$ and $E_{\mathrm{m}}\left(\mathrm{Chl}_{\mathrm{D} 2}\right)$ in $\mathrm{mV}$. - , not applicable

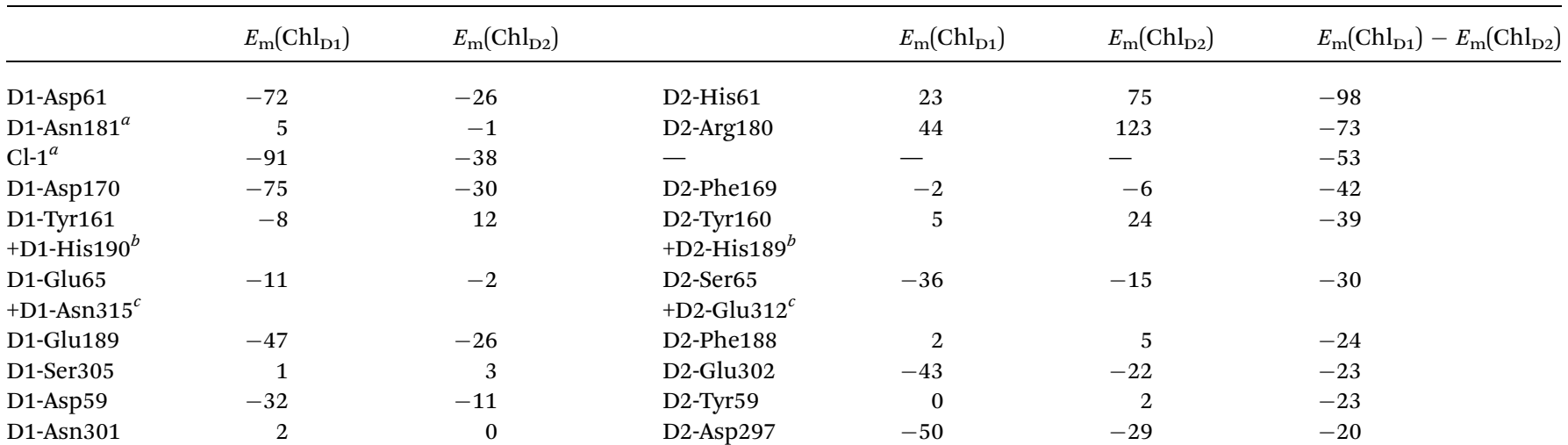

${ }^{a} \mathrm{Cl}-1$ and D1-Asn181 interact directly $\left(\mathrm{Cl}^{-} \cdots \mathrm{N}_{\mathrm{D} 1-\mathrm{Asn} 181}=3.31 \AA^{5}\right) .{ }^{b}$ D1-Tyr161 and D1-His190 form an H-bond, sharing a proton. D2-Tyr160 and D2His189 form an H-bond, sharing a proton. ${ }^{c}$ D1-Glu65 and D2-Glu312 form an H-bond, sharing a proton.

facilitate L-branch electron transfer. If $\mathrm{P}_{\mathrm{D} 1}$ and $\mathrm{P}_{\mathrm{D} 2}$ could form the strongly coupled $\mathrm{P}_{\mathrm{D} 1} / \mathrm{P}_{\mathrm{D} 2}$ special pair and function as an initial electron donor, electronic excitation of the $\mathrm{P}_{\mathrm{D} 1} / \mathrm{P}_{\mathrm{D} 2}$ pair might possibly have led to electron transfer in the D2-branch, since $E_{\mathrm{m}}\left(\mathrm{PheO}_{\mathrm{D} 2}\right)$ is sufficiently higher than $E_{\mathrm{m}}\left(\mathrm{Chl}_{\mathrm{D} 2}\right)$ (Fig. 2). However, the electronic coupling between $\mathrm{P}_{\mathrm{D} 1}$ and $\mathrm{P}_{\mathrm{D} 2}$ (85 to $150 \mathrm{~cm}^{-1}$ (ref. 49 and 50)) in PSII is much weaker than that between $P_{L}$ and $P_{M}\left(500\right.$ to $1000 \mathrm{~cm}^{-1}$ (ref. 51)) in PbRC. In addition, the longest wavelength pigment is thought to be $\mathrm{Chl}_{\mathrm{D} 1}$ in PSII. ${ }^{\mathbf{5 0 , 5 2}}$ Given that $\mathrm{Chl}_{\mathrm{D} 1}$ is the primary electron donor (i.e., Chla, where excitation occurs due to the lowest site-energy) in PSII (e.g. $\left.{ }^{53}\right)$, the calculated $E_{\mathrm{m}}$ values indicate that electron transfer can occur in the D1-branch because of the sufficiently high $E_{\mathrm{m}}\left(\mathrm{Pheo}_{\mathrm{D} 1}\right)$ value $\left(-500 \mathrm{mV}^{31,33}\right.$ and Fig. 2).

Hence, it seems likely that PSII activates electron transfer in the D1-branch (i) by uncoupling the $\mathrm{P}_{\mathrm{D} 1} / \mathrm{P}_{\mathrm{D} 2}$ pair (i.e., making both electron-transfer branches electronically completely isolated) and (ii) by employing $\mathrm{Chl}_{\mathrm{D} 1}$ as the primary electron donor; in contrast, PbRC activates electron transfer in the
L-branch by increasing $E_{\mathrm{m}}\left(\mathrm{B}_{\mathrm{L}}\right)$ with respect to $E_{\mathrm{m}}\left(\mathrm{B}_{\mathrm{M}}\right)$ in the presence of the strongly coupled $\mathrm{P}_{\mathrm{L}} / \mathrm{P}_{\mathrm{M}}$ pair.

\section{Influence of the periplasm/lumen region on $E_{m}$ for accessory (B)Chla}

In PbRC, among the total $E_{\mathrm{m}}$ difference of $168 \mathrm{mV}$ between $\mathrm{B}_{\mathrm{L}}$ and $\mathrm{B}_{\mathrm{M}}$ (where $E_{\mathrm{m}}\left(\mathrm{B}_{\mathrm{L}}\right)>E_{\mathrm{m}}\left(\mathrm{B}_{\mathrm{M}}\right)$ ), $80 \mathrm{mV}$ originates from the periplasm region, namely loop $a-b(47 \mathrm{mV})$ and helix $c d(40 \mathrm{mV})$; in PSII, among the total $E_{\mathrm{m}}$ difference of $-117 \mathrm{mV}$ between $\mathrm{Chl}_{\mathrm{D} 1}$ and $\mathrm{Chl}_{\mathrm{D} 2}$ (where $E_{\mathrm{m}}\left(\mathrm{Chl}_{\mathrm{D} 1}\right)<E_{\mathrm{m}}\left(\mathrm{Chl}_{\mathrm{D} 2}\right)$ ), $-132 \mathrm{mV}$ originates from the corresponding lumen region, namely loop $a-b(-86 \mathrm{mV})$ and helix $c d(-91 \mathrm{mV})$ (Table 2). Thus, loop $a-b$ and helix $c d$ in the periplasm/lumen region primarily contribute to the different $E_{\mathrm{m}}$ profiles (Fig. 2) for PbRC and PSII.

In PbRC, acidic residues Asp-M184 in helix $c d$ and Glu-M95 in loop $a-b$, which contribute to $E_{\mathrm{m}}\left(\mathrm{B}_{\mathrm{L}}\right)>E_{\mathrm{m}}\left(\mathrm{B}_{\mathrm{M}}\right)$ (Table 3), serve as an $\mathrm{H}$-bond network for the binding of cytochrome $c_{2}$, the source of electrons for $\left[\mathrm{P}_{\mathrm{L}} / \mathrm{P}_{\mathrm{M}}\right]^{0+}$. In PSII, basic residues D2-Arg180 in helix $c d$ and D2-His61 in loop $a-b$, which contribute to $E_{\mathrm{m}}\left(\mathrm{Chl}_{\mathrm{D} 1}\right)$ $<E_{\mathrm{m}}\left(\mathrm{Chl}_{\mathrm{D} 2}\right)$ (Table 4), serve as a proton-conducting H-bond a)

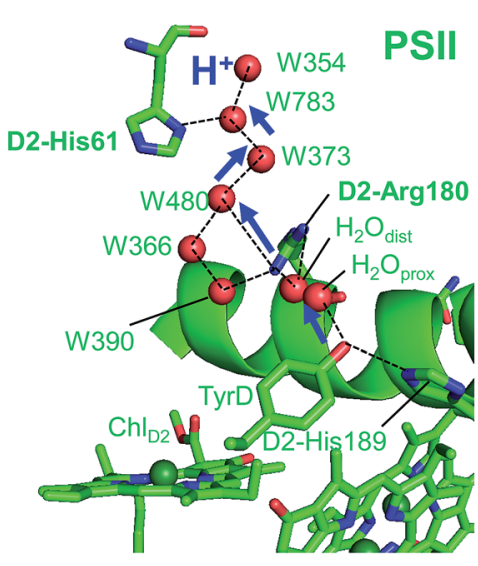

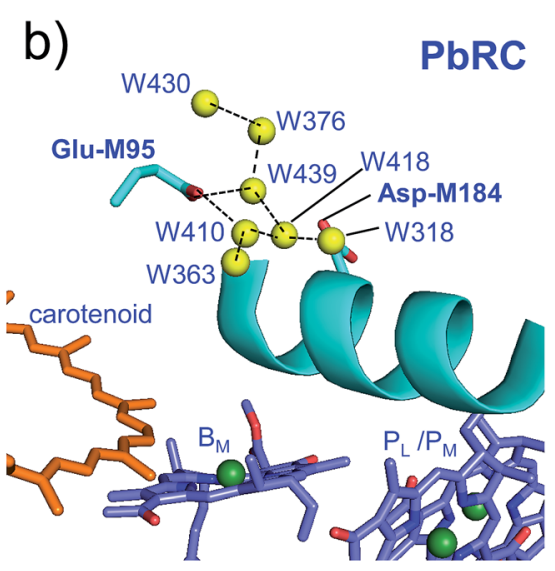

Fig. 5 (a) $\mathrm{H}$-bond network of water molecules (red balls) near $\mathrm{Chl}_{\mathrm{D} 2}$ in PSII (green), serving as a proton transfer pathway from TyrD (blue arrows) ${ }^{44,47}$ and (b) the corresponding $\mathrm{H}$-bond network of water molecules (yellow balls) near $\mathrm{B}_{\mathrm{M}}$ in PbRC (cyan). The carotenoid molecule (spheroidene) exists only in $\mathrm{PbRC}$. 
network proceeding from TyrD $\mathrm{D}^{44,46,47}$ and also increase the $\mathrm{P}_{\mathrm{D} 1}{ }^{\cdot+}$ population with respect to $\mathrm{P}_{\mathrm{D} 2}{ }^{++}$in $\left[\mathrm{P}_{\mathrm{D} 1} / \mathrm{P}_{\mathrm{D} 2}\right]^{++} .^{13}$

Intriguingly, Asp-M184 in helix $c d$ and Glu-M95 in loop $a-$ $b$ in PbRC correspond to D2-Arg180 in helix $c d$ and D2-His61 in loop $a-b$ in PSII, respectively (Fig. 5 and S $\$ \dagger$ ). Furthermore, even water molecules in the proton transfer pathway from TyrD in PSII seem to be structurally conserved on the binding surface near Asp-M184 and Glu-M95 in PbRC (Fig. 5b). These structural features imply that the cytochrome $c_{2}$ binding network in PbRC and the proton transfer pathway from TyrD in PSII have a common origin, which differentiate the mechanism of singlebranch electron transfer between PbRC and PSII.

From the involvement of Asp-M184 in the binding interface with cytochrome $c_{2}$ and correspondence of Asp-M184 to D2Arg180 (Fig. S9†), the electrostatic differences in the periplasm/lumen regions are likely associated with the difference in sources of electrons-cytochrome $c_{2} / \mathrm{H}_{2} \mathrm{O}$.

\section{Type-I reaction centers with respect to type-II reaction centers}

In PSII, residues that increase the $E_{\mathrm{m}}$ difference between $\mathrm{Chl}_{\mathrm{D} 1}$ and $\mathrm{Chl}_{\mathrm{D} 2}$ (Table 2) are mostly identical to those that have been identified to increase the $E_{\mathrm{m}}$ difference between $\mathrm{P}_{\mathrm{D} 1}$ and $\mathrm{P}_{\mathrm{D} 2}$ significantly ${ }^{13}$ (e.g., D1-Asp61/D2-His61, D1-Asn181/D2-Arg180, D1-Asp170/D2-Phe169, and D1-Glu189/D2-Phe188). These results suggest that the same PSII protein electrostatic environment (discussed above) is responsible for asymmetry in energetics of the electron transfer branches (Fig. 2) as well as the cationic state distribution over the $\left[\mathrm{P}_{\mathrm{D} 1} / \mathrm{P}_{\mathrm{D} 2}\right]^{++} .^{13}$

In PSI, the protein electrostatic environments of PsaA and $\mathrm{PsaB}$ are quite similar and no residues have been identified to induce the $E_{\mathrm{m}}$ difference between $\mathrm{P}_{\mathrm{A}}$ and $\mathrm{P}_{\mathrm{B}}$ significantly. ${ }^{27}$ Indeed, $E_{\mathrm{m}}\left(\mathrm{A}_{1 \mathrm{~A}}\right)$ and $E_{\mathrm{m}}\left(\mathrm{A}_{1 \mathrm{~B}}\right)$ are also similar (Fig. 2a and $\mathrm{S} 1 \dagger$ ) and there are no residues that induce the $E_{\mathrm{m}}$ difference between $\mathrm{A}_{1 \mathrm{~A}}$ and $\mathrm{A}_{1 \mathrm{~B}}$. It seems likely that the similar protein electrostatic environment of PsaA and PsaB is a main factor that plays a role in keeping both branches open for electron transfer in PSI.

\section{Concluding remarks}

In PSII, substrate water molecules need to release protons when acting as an electron donor; thus, both electron and proton transfer pathways are expected to proceed from the substrate water molecules. The proton transfer pathway from $\mathrm{O} 4$ and the electron transfer pathway toward $\mathrm{P}_{\mathrm{D} 1}{ }^{++}$go along the same axis in the opposite directions (Fig. 6), which allows PSII to use the common protein electrostatic environment for both transfer of electrons $\left(\mathrm{e}^{-}\right)$and protons $\left(\mathrm{H}^{+}\right)$without competing. It seems plausible that $E_{\mathrm{m}}\left(\mathrm{Chl}_{\mathrm{D} 1}\right)<E_{\mathrm{m}}\left(\mathrm{Chl}_{\mathrm{D} 2}\right)$ in PSII, which is obviously inconsistent with $E_{\mathrm{m}}\left(\mathrm{B}_{\mathrm{L}}\right)>E_{\mathrm{m}}\left(\mathrm{B}_{\mathrm{M}}\right)$ in $\mathrm{PbRC}$, is due to a compromise between release of protons and release of electrons from the substrate water molecules using the common protein electrostatic environment and could have been overcome (i) by uncoupling the $\mathrm{P}_{\mathrm{D} 1} / \mathrm{P}_{\mathrm{D} 2}$ pair and (ii) by employing $\mathrm{Chl}_{\mathrm{D} 1}$ as the primary electron donor.

Hence, it is likely not a coincidence that the D1/D2 residue pairs, which are responsible for $E_{\mathrm{m}}\left(\mathrm{Chl}_{\mathrm{D} 1}\right)<E_{\mathrm{m}}\left(\mathrm{Chl}_{\mathrm{D} 2}\right)($ e.g.,
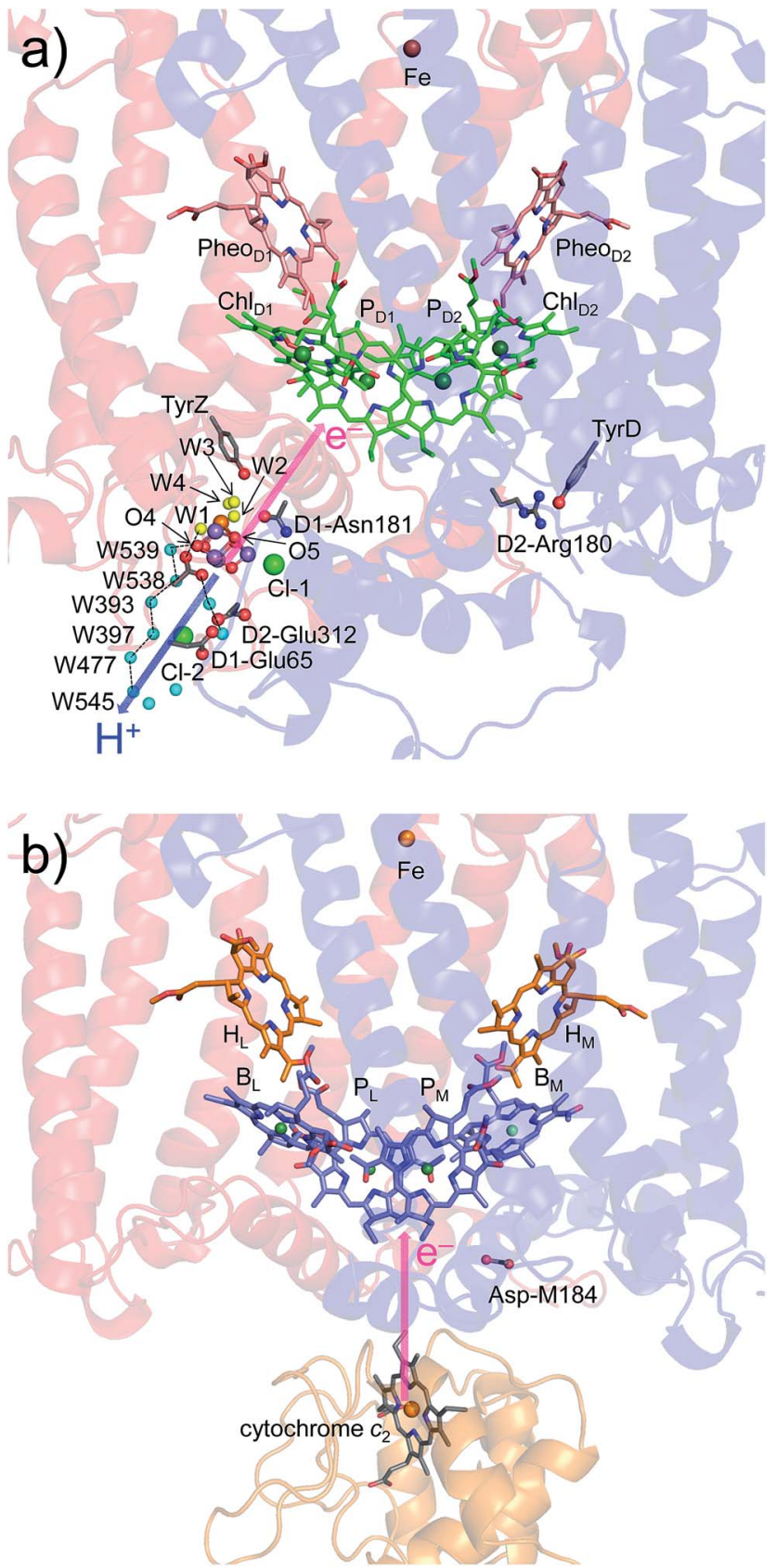

Fig. 6 Locations of the electron transfer (pink arrows) and proton transfer (blue arrow) pathways in (a) PSII and (b) PbRC. Ligand water molecules are indicated by yellow balls and other water molecules by cyan balls. PbRCs from Rhodobacter sphaeroides and Blastochloris viridis have cytochrome $c_{2}$ and a bound tetraheme cytochrome as the source of electrons, respectively. In both $\mathrm{PbRCs}$, the sources of electrons are at an equidistance of 20-21 A from $\mathrm{P}_{\mathrm{L}}$ and $\mathrm{P}_{\mathrm{M}}$. In PSII, W539 (21.4 $\AA), O 4(19.7 \AA)$, and $W 1(18.5 \AA)$ are at similar distances $\left(\sim 20 \AA\right.$ ) from the electron acceptor (monomeric $\mathrm{P}_{\mathrm{D} 1}{ }^{\cdot+}$ ).

D1-Asn181/D2-Arg180 and D1-Asp61/D2-His61), can also serve as (i) electrostatically pushing the cation onto $\mathrm{P}_{\mathrm{D} 1}$ [basic residues in D2] ${ }^{14}$ providing a larger $\mathrm{P}_{\mathrm{D} 1}{ }^{.+}$population than $\mathrm{P}_{\mathrm{D} 2}{ }^{.+}$(ref. 13) and thereby facilitating electron transfer from substrate water molecules in $\mathrm{D} 1 .^{15}$ The presence of low $\mathrm{p} K_{\mathrm{a}}$ groups (i.e., acidic residues) near the proton releasing $\mathrm{Mn}_{4} \mathrm{CaO}_{5}$ site [acidic residues in 
D1] also (ii) facilitates release of protons from the substrate water molecules. These features seem to be the nature of PSII, which uses a protonated electron source-a pair of water molecules.

\section{Methods}

\section{Coordinates and atomic partial charges}

The atomic coordinates were taken from the X-ray structures; cyanobacterial PSI from Thermosynechococcus elongatus at $2.5 \AA$ resolution (PDB code, 1JB0); ${ }^{2}$ plant PSI from Pisum sativum at $2.8 \AA$ resolution (PDB code, 4XK8); PbRC from Rhodobacter sphaeroides at $2.01 \AA$ resolution (PDB code, 3I4D), $1.87 \AA$ resolution (PDB code, 2J8C), ${ }^{4}$ and $2.55 \AA$ resolution (PDB code, $1 \mathrm{M} 3 \mathrm{X}){ }^{3}$ PbRC from Thermochromatium tepidum at $2.2 \AA$ resolution (PDB code, 1EYS); ${ }^{30}$ the PSII monomer unit (designated monomer A) of the PSII complexes from Thermosynechococcus vulcanus at $1.9 \AA$ A resolution (PDB code, 3ARC). ${ }^{5}$ Hydrogen atoms were generated and energetically optimized with CHARMM. ${ }^{54}$ Atomic partial charges of the amino acids were adopted from the all-atom CHARMM22) parameter set. ${ }^{55}$ For PSI, the atomic charges of cofactors were taken from previous studies (Chla, phylloquinone, $\beta$-carotene, ${ }^{56}$ and the $\mathrm{Fe}_{4} \mathrm{~S}_{4}$ cluster $\left.{ }^{57}\right)$. The atomic charges of the other cofactors ((B)Chla, including (B) $\mathrm{Chl} a^{\cdot+}$ and (B)Chl $a^{\cdot-}$, (B)Pheo $a$, ubiquinone, plastoquinone, spheroidene, sulfoquinovosyl diacylglycerol, heptyl 1-thiohexopyranoside, and the Fe complex) were determined by fitting the electrostatic potential in the neighborhood of these molecules using the RESP procedure ${ }^{58}$ (Tables S2-S11†). To obtain the atomic charges of the $\mathrm{Mn}_{4} \mathrm{CaO}_{5}$ cluster or the Fe complex, backbone atoms are not included in the RESP procedure (except for D1-Ala344) (Table S11 $\dagger$ ). The electronic wave functions were calculated after geometry optimization by the DFT method with the B3LYP functional and $6-31 \mathrm{G}^{* *}$ basis sets, using the JAGUAR program. ${ }^{59}$ For the atomic charges of the non-polar $\mathrm{CH}_{n}$ groups in cofactors (e.g., the phytol chains of (B)Chl $a$ and (B)Pheo $a$ and the isoprene side-chains of quinones), the value of +0.09 was assigned for non-polar $\mathrm{H}$ atoms. We considered the $\mathrm{Mn}_{4} \mathrm{CaO}_{5}$ cluster to be fully deprotonated in $S_{1}$.

The protein inner spaces were represented implicitly with the dielectric constant $\varepsilon_{\mathrm{w}}=80$, whereas the following water molecules were represented explicitly; (i) for PSII, ligand water molecules of the $\mathrm{Mn}_{4} \mathrm{CaO}_{5}$ cluster (W1 to W4), a diamondshaped cluster of water molecules near TyrZ (W5 to W7 ${ }^{\mathbf{6 0}}$, the water molecule distal to $\mathrm{TyrD}^{\mathbf{4 4}}$, ligand water molecules of $\mathrm{Chl}_{\mathrm{D} 1}$ (A1003 and D424), $\mathrm{Chl}_{\mathrm{D} 2}$ (A1009 and A359), and other Chla (B1001, B1007, B1027, C816, and C1004); (ii) for PSI, clusters of water molecules near $\mathrm{A}_{1 \mathrm{~A}}$ (A5007, A5015, A5022, A5043, and A5049) and $\mathrm{A}_{1 \mathrm{~B}}$ (B5018, B5019, B5030, B5055, B5056, and B5058), ligand water molecules of $\mathrm{A}_{-1 \mathrm{~A}}$ (B5005), $\mathrm{A}_{-1 \mathrm{~B}}$ (A5005), and other Chla (A5004, A5010, A5012, A5024, A5032, A5051, B5006, B5010, B5022, B5036, B5053, B5054, J127, L4023, and M155).

\section{$E_{\mathrm{m}}$ calculation: solving the linear Poisson-Boltzmann equation}

To obtain the $E_{\mathrm{m}}$ values in the proteins, we calculated the electrostatic energy difference between the two redox states in a reference model system by solving the linear Poisson-Boltzmann equation with the MEAD program ${ }^{61}$ and using $E_{\mathrm{m}}(\mathrm{BChl} a)$ $=-641 \mathrm{mV}, E_{\mathrm{m}}(\mathrm{BPheo} a)=-384 \mathrm{mV}\left(\right.$ based on $E_{\mathrm{m}}(\mathrm{BChl} a)=$ $-830 \mathrm{mV}$ and $E_{\mathrm{m}}(\mathrm{BPheo} a)=-600 \mathrm{mV}$ for one-electron reduction measured in tetrahydrofuran, ${ }^{62}$ considering the solvation energy difference), $E_{\mathrm{m}}(\mathrm{Chl} a)=-798 \mathrm{mV}$, and $E_{\mathrm{m}}($ Pheo $a)=$ $-641 \mathrm{mV}$ (based on $E_{\mathrm{m}}(\mathrm{Chl} a)=-910 \mathrm{mV}$ and $E_{\mathrm{m}}($ Pheo $a)=$ $-700 \mathrm{mV}$ for one-electron reduction measured in butyronitrile $\left.{ }^{63}\right)$. The difference in the $E_{\mathrm{m}}$ value of the protein relative to the reference system was added to the known $E_{\mathrm{m}}$ value. The ensemble of the protonation patterns was sampled by the Monte Carlo method with Karlsberg. ${ }^{64}$ The linear PoissonBoltzmann equation was solved using a three-step grid-focusing procedure at resolutions of $2.5 \AA$ A $1.0 \AA$, and $0.3 \AA$. Monte Carlo sampling yielded the probabilities $\left[\mathrm{A}_{\text {ox }}\right]$ and $\left[\mathrm{A}_{\text {red }}\right]$ of the two redox states of molecule A. $E_{\mathrm{m}}$ was evaluated using the Nernst equation. A bias potential was applied to obtain an equal amount of both redox states $\left(\left[\mathrm{A}_{\mathrm{ox}}\right]=\left[\mathrm{A}_{\mathrm{red}}\right]\right)$, thereby yielding the redox midpoint potential as the resulting bias potential. To facilitate direct comparisons with previous computational results $\left(\right.$ e.g. $\left.{ }^{\mathbf{1 3 2 6}}\right)$, identical computational conditions and parameters were used; all computations were performed at

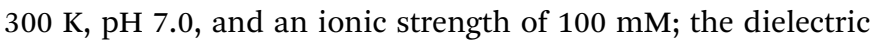
constants were set to $\varepsilon_{\mathrm{p}}=4$ inside the protein and $\varepsilon_{\mathrm{w}}=80$ for water.

\section{Conflicts of interest}

There are no conflicts to declare.

\section{Acknowledgements}

This research was supported by JST CREST (JPMJCR1656), JSPS KAKENHI (JP16H06560 and JP26105012), Japan Agency for Medical Research and Development (AMED), Materials Integration for engineering polymers of Cross-ministerial Strategic Innovation Promotion Program (SIP), and the Interdisciplinary Computational Science Program in CCS, University of Tsukuba.

\section{References}

$1 \mathrm{H}$. Michel and J. Deisenhofer, Biochemistry, 1988, 27, 1-7.

2 P. Jordan, P. Fromme, H. T. Witt, O. Klukas, W. Saenger and N. Krauss, Nature, 2001, 411, 909-917.

3 A. Camara-Artigas, D. Brune and J. P. Allen, Proc. Natl. Acad. Sci. U. S. A., 2002, 99, 11055-11060.

4 J. Koepke, E. M. Krammer, A. R. Klingen, P. Sebban, G. M. Ullmann and G. Fritzsch, J. Mol. Biol., 2007, 371, 396-409.

5 Y. Umena, K. Kawakami, J.-R. Shen and N. Kamiya, Nature, 2011, 473, 55-60.

6 X. Qin, M. Suga, T. Kuang and J. R. Shen, Science, 2015, 348, 989-995.

7 T. Watanabe, M. Kobayashi, A. Hongu, M. Nakazato, T. Hiyama and N. Murata, FEBS Lett., 1985, 191, 252-256.

8 P. Joliot and A. Joliot, Biochemistry, 1999, 38, 11130-11136. 
9 T. Cardona, A. Sedoud, N. Cox and A. W. Rutherford, Biochim. Biophys. Acta, 2012, 1817, 26-43.

10 J. C. Williams, R. G. Alden, H. A. Murchison, J. M. Peloquin, N. W. Woodbury and J. P. Allen, Biochemistry, 1992, 31, 11029-11037.

11 V. V. Klimov, S. I. Allakhverdiev, S. Demeter and A. A. Krasnovskii, Dokl. Akad. Nauk SSSR, 1979, 249, 227-230.

12 A. W. Rutherford, J. E. Mullet and A. R. Crofts, FEBS Lett., 1981, 123, 235-237.

13 K. Saito, T. Ishida, M. Sugiura, K. Kawakami, Y. Umena, N. Kamiya, J.-R. Shen and H. Ishikita, J. Am. Chem. Soc., 2011, 133, 14379-14388.

14 A. W. Rutherford, A. Boussac and P. Faller, Biochim. Biophys. Acta, 2004, 1655, 222-230.

15 P. Faller, R. J. Debus, K. Brettel, M. Sugiura, A. W. Rutherford and A. Boussac, Proc. Natl. Acad. Sci. U. S. A., 2001, 98, 1436814373.

16 H. Dau and M. Haumann, Coord. Chem. Rev., 2008, 252, 273295.

17 M. Haumann and W. Junge, Biochim. Biophys. Acta, 1999, 1411, 86-91.

18 J. S. Vrettos, J. Limburg and G. W. Brudvig, Biochim. Biophys. Acta, 2001, 1503, 229-245.

19 G. Renger, Biochim. Biophys. Acta, 2001, 1503, 210-228.

20 K. Saito, A. W. Rutherford and H. Ishikita, Nat. Commun., 2015, 6, 8488.

21 K. N. Ferreira, T. M. Iverson, K. Maghlaoui, J. Barber and S. Iwata, Science, 2004, 303, 1831-1838.

22 H. Ishikita, W. Saenger, B. Loll, J. Biesiadka and E.-W. Knapp, Biochemistry, 2006, 45, 2063-2071.

23 N. W. Woodbury and W. W. Parson, Biochim. Biophys. Acta, 1984, 767, 345-361.

24 M. R. Gunner, A. Nicholls and B. Honig, J. Phys. Chem., 1996, 100, 4277-4291.

25 A. W. Rutherford, A. Osyczka and F. Rappaport, FEBS Lett., 2012, 586, 603-616.

26 H. Ishikita, W. Saenger, J. Biesiadka, B. Loll and E.-W. Knapp, Proc. Natl. Acad. Sci. U. S. A., 2006, 103, 9855-9860.

27 K. Saito and H. Ishikita, Biophys. J., 2011, 101, 2018-2025.

28 F. A. M. Kleinherenbrink, G. Hastings, B. P. Wittmershaus and R. E. Blankenship, Biochemistry, 1994, 33, 3096-3105.

29 S. Kumazaki, M. Iwaki, I. Ikegami, H. Kandori, K. Yoshihara and S. Itoh, J. Phys. Chem., 1994, 98, 11220-11225.

30 T. Nogi, I. Fathir, M. Kobayashi, T. Nozawa and K. Miki, Proc. Natl. Acad. Sci. U. S. A., 2000, 97, 13561-13566.

31 H. Ishikita, J. Biesiadka, B. Loll, W. Saenger and E.-W. Knapp, Angew. Chem., Int. Ed., 2006, 45, 1964-1965.

32 B. Loll, J. Kern, W. Saenger, A. Zouni and J. Biesiadka, Nature, 2005, 438, 1040-1044.

33 Y. Kato, M. Sugiura, A. Oda and T. Watanabe, Proc. Natl. Acad. Sci. U. S. A., 2009, 106, 17365-17370.

34 W. Holzapfel, U. Finkele, W. Kaiser, D. Oesterhelt, H. Scheer, H. U. Stilz and W. Zinth, Chem. Phys. Lett., 1989, 160, 1-7.

35 H. L. Axelrod, E. C. Abresch, M. Y. Okamura, A. P. Yeh, D. C. Rees and G. Feher, J. Mol. Biol., 2002, 319, 501-515.

36 M. Tetreault, S. H. Rongey, G. Feher and M. Y. Okamura, Biochemistry, 2001, 40, 8452-8462.
37 W. W. Parson, Z.-T. Chu and A. Warshel, Biochim. Biophys. Acta, 1990, 1017, 251-272.

38 U. Finkele, C. Lauterwasser, W. Zinth, K. A. Gray and D. Oesterhelt, Biochemistry, 1990, 29, 8517-8521.

39 A. W. Roszak, K. McKendrick, A. T. Gardiner, I. A. Mitchell, N. W. Isaacs, R. J. Cogdell, H. Hashimoto and H. A. Frank, Structure, 2004, 12, 765-773.

40 M. A. Steffen, K. Lao and S. G. Boxer, Science, 1994, 264, 810816.

41 N. Sakashita, H. C. Watanabe, T. Ikeda and H. Ishikita, Photosynth. Res., 2017, 133, 75-85.

42 N. Sakashita, H. C. Watanabe, T. Ikeda, K. Saito and H. Ishikita, Biochemistry, 2017, 56, 3049-3057.

43 A. G. Gabdulkhakov, V. G. Kljashtorny and M. V. Dontsova, Crystallogr. Rep., 2015, 60, 884-888.

44 K. Saito, A. W. Rutherford and H. Ishikita, Proc. Natl. Acad. Sci. U. S. A., 2013, 110, 7690-7695.

45 R. J. Service, W. Hillier and R. J. Debus, Biochemistry, 2010, 49, 6655-6669.

46 S. Nakamura and T. Noguchi, Biochemistry, 2015, 54, 50455053.

47 K. Saito, N. Sakashita and H. Ishikita, Aust. J. Chem., 2016, 69, 991-998.

48 M. Zhang, M. Bommer, R. Chatterjee, R. Hussein, J. Yano, H. Dau, J. Kern, H. Dobbek and A. Zouni, eLife, 2017, 6, e26933.

49 J. R. Durrant, D. R. Klug, S. L. Kwa, R. van Grondelle, G. Porter and J. P. Dekker, Proc. Natl. Acad. Sci. U. S. A., 1995, 92, 4798-4802.

50 G. Raszewski, B. A. Diner, E. Schlodder and T. Renger, Biophys. J., 2008, 95, 105-119.

51 N. W. Woodbury and J. P. Allen, in Anoxygenic photosynthetic bacteria: advances in photosynthesis, ed. R. E. Blankenship, M. T. Madigan and C. E. Bauer, Kluwer Academic Publishers, Dordrecht, 1995, pp. 527-557.

52 N. Cox, J. L. Hughes, R. Steffen, P. J. Smith, A. W. Rutherford, R. J. Pace and E. Krausz, J. Phys. Chem. B, 2009, 113, 1236412374.

53 B. A. Diner and F. Rappaport, Annu. Rev. Plant Biol., 2002, 53, 551-580.

54 B. R. Brooks, R. E. Bruccoleri, B. D. Olafson, D. J. States, S. Swaminathan and M. Karplus, J. Comput. Chem., 1983, 4, 187-217.

55 A. D. MacKerell Jr, D. Bashford, R. L. Bellott, R. L. Dunbrack Jr, J. D. Evanseck, M. J. Field, S. Fischer, J. Gao, H. Guo, S. Ha, D. Joseph-McCarthy, L. Kuchnir, K. Kuczera, F. T. K. Lau, C. Mattos, S. Michnick, T. Ngo, D. T. Nguyen, B. Prodhom, W. E. Reiher III, B. Roux, M. Schlenkrich, J. C. Smith, R. Stote, J. Straub, M. Watanabe, J. Wiorkiewicz-Kuczera, D. Yin and M. Karplus, J. Phys. Chem. B, 1998, 102, 35863616.

56 K. Kawashima and H. Ishikita, Biochemistry, 2017, 56, 30193028.

57 J. Mouesca, J. L. Chen, L. Noodleeman, D. Bashford and D. A. Case, J. Am. Chem. Soc., 1994, 116, 11898-11914.

58 C. I. Bayly, P. Cieplak, W. D. Cornell and P. A. Kollman, J. Phys. Chem., 1993, 97, 10269-10280. 
59 Jaguar, version 7.9, Schrödinger, LLC, New York, NY, 2011. 60 K. Saito, J.-R. Shen, T. Ishida and H. Ishikita, Biochemistry, 2011, 50, 9836-9844.

61 D. Bashford and M. Karplus, Biochemistry, 1990, 29, 1021910225.
62 T. M. Cotton and R. P. van Duyne, J. Am. Chem. Soc., 1979, 101, 7605-7612.

63 T. Watanabe and M. Kobayashi, in Chlorophylls, ed. H. Scheer, CRC Press, Boca Raton, FL, 1991, pp. 287-303.

64 B. Rabenstein and E. W. Knapp, Biophys. J., 2001, 80, 1141-1150. 